\title{
Evaluation of Prostate Cancer with ${ }^{11} \mathrm{C}$-Acetate PET/CT
}

\author{
Claudio Spick, Ken Herrmann, and Johannes Czernin \\ Ahmanson Translational Imaging Division, Department of Molecular and Medical Pharmacology, David Geffen School \\ of Medicine at UCLA, Los Angeles, California
}

In this article, we will first describe the metabolic fate of ${ }^{11} \mathrm{C}$-acetate; then discuss its biodistribution in health and disease; and subsequently focus on its key clinical applications, the detection and localization of prostate cancer tissue in patients with primary or recurrent disease. Finally, we will discuss the potential role of ${ }^{11} \mathrm{C}$ acetate in the context of other prostate cancer imaging probes and non-radionuclide-based imaging approaches.

J Nucl Med 2016; 57:30S-37S

DOI: 10.2967/jnumed.115.169599

dentifying those primary prostate cancers that require aggressive interventions and localizing the origin of biochemical recurrence remain important yet still elusive clinical needs. Molecular imaging provides a diverse portfolio of PET probes for phenotyping and localizing prostate cancer tissue, including peptide and hormone receptor ligands and small molecules for metabolic phenotyping. The best use of these probes as diagnostic, predictive, and intermediate endpoint biomarkers within the framework of other available diagnostic tools has yet to be determined.

${ }^{11} \mathrm{C}$-acetate was originally used for PET measurements of myocardial oxidative metabolism because acetate enters the Krebs cycle after conversion to acetyl coenzyme A (CoA) to meet cellular energy demands (1-4). However, acetate has a diverse metabolic fate because it is also a substrate for lipid and cholesterol synthesis (5-7). Therefore, its increased cellular uptake reflects the increased membrane lipid demands of proliferating tissues.

The biology and clinical role of probing membrane lipid synthesis with ${ }^{11} \mathrm{C}$ - and ${ }^{18} \mathrm{~F}$-choline are discussed extensively elsewhere in this supplement. Suffice it to say that choline has its own transporter, and the rate-limiting enzyme in its synthetic (Kennedy) pathway (8) is choline kinase. Yet both acetate and choline are incorporated into membrane phospholipids in cancer cells and thus are likely to reflect the same process-that is, the increased demand for these lipids in cancers with increased cell turnover.

\section{BIOLOGIC CORRELATES OF ${ }^{11} \mathrm{C}$-ACETATE IN PROSTATE CANCER}

Acetate is an important substrate in the energy metabolism of cells. As an essential intermediate in catabolic and biosynthetic

Received Feb. 8, 2016; revision accepted Mar. 10, 2016.

For correspondence or reprints contact: Johannes Czernin, David Geffen School of Medicine at UCLA, 10833 Le Conte Ave., 200 Medical Plaza, Ste. B114-61, Los Angeles, CA 90095-7370.

E-mail: jczernin@mednet.ucla.edu

COPYRIGHT (c) 2016 by the Society of Nuclear Medicine and Molecular Imaging, Inc. processes, its intracellular fate is diverse. On one hand, it is transported into tissues via the monocarboxylate transporter and is further metabolized to $\mathrm{CO}_{2}$ via the tricarboxylic acid cycle. This metabolic pathway has been exploited for imaging and quantifying myocardial oxidative metabolism (9-13). However, acetate use in cancer cells is governed predominantly by another metabolic process (Fig. 1). Cancer cells have an increased requirement for cell membrane lipids. In fact, acetate is the only carbon source for fatty acid and cholesterol synthesis. The rate-limiting enzyme in this pathway is fatty acid synthase (FAS). Its increased expression promotes de novo fatty acid synthesis from CoA, malonyl-CoA, and nicotinamide adenine dinucleotide phosphate in normal and abnormal tissues and meets the increased demand for membrane lipids $(7,14,15)$. Overexpression of FAS correlates with prostate cancer aggressiveness (16) and high Gleason scores (17).

In support of the notion that FAS is the rate-limiting enzyme, in vitro studies have shown that cellular ${ }^{11} \mathrm{C}$-acetate uptake can be blocked with inhibitors of FAS and acetyl-CoA carboxylase (18). ${ }^{11} \mathrm{C}$-acetate uptake may therefore serve as a biomarker of FAS activity and thus of an important metabolic process in cancer, namely the increased lipid synthesis required for maintaining cell membrane integrity. ${ }^{11} \mathrm{C}$-acetate uptake may also serve as a pharmacodynamic biomarker of interventions targeting lipid synthesis in cancer.

\section{${ }^{11} \mathrm{C}$-ACETATE BIODISTRIBUTION AND DOSIMETRY}

The first synthesis of ${ }^{11} \mathrm{C}$-acetate dates back to 1943 , when Buchanan et al. (19) labeled acetic, propionic, and butyric acids with ${ }^{11} \mathrm{C}$ to determine contributions to liver glycogen synthesis. Subsequent synthesis approaches resulted in initial human biodistribution studies using an Anger camera (20). High-quality tomographic images of the human heart were first acquired by Pike et al. (21) in 1982, who used a scanner based on the design by Hoffman and Phelps (22).

The earliest reports on ${ }^{11} \mathrm{C}$-acetate imaging in cancer date back to 1995, when Shreve et al. (23) reported different tracer kinetics among normal myocardium, normal renal parenchyma, and renal cancer tissue. Myocardial and normal renal tissue showed rapid washout consistent with predominant oxidation to $\mathrm{CO}_{2}$ via the tricarboxylic acid cycle. In contrast, tracer was retained in tumor tissue, probably because of the use of ${ }^{11} \mathrm{C}$ acetate as an important substrate for the generation of membrane lipids.

Systematic biodistribution and dosimetry studies (Fig. 2) were conducted by Seltzer et al. (24). They demonstrated early tracer accumulation in the myocardium, kidneys, pancreas, spleen, and bone marrow. In an advantage for prostate imaging, urinary bladder activity was notably absent because of the active reabsorption 


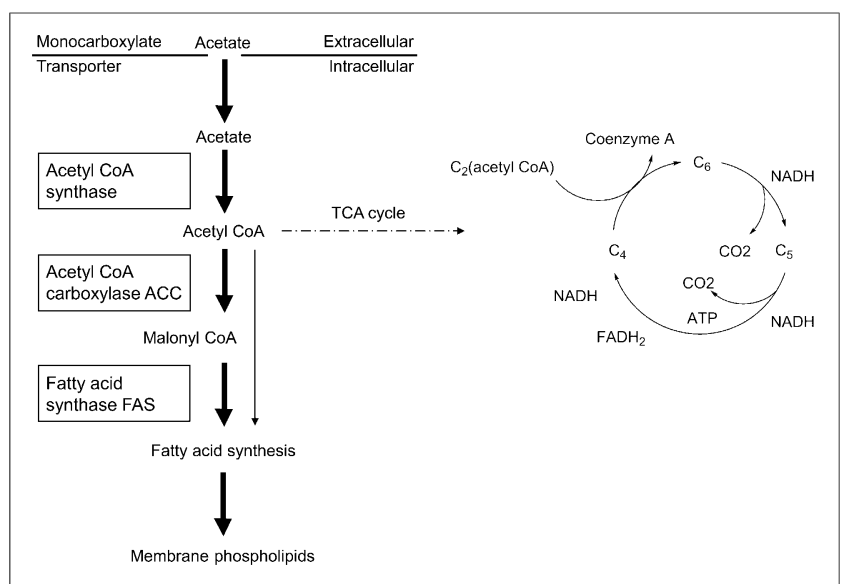

FIGURE 1. Fatty acid synthesis from acetate. Acetate is transported across cell membranes via monocarboxylate transporter and converted to acetyl CoA. It is then further metabolized by acetyl CoA carboxylase to malonyl CoA. FAS-the rate-limiting enzyme in fatty acid synthesis and ${ }^{11} \mathrm{C}$-acetate metabolism-further processes both acetyl CoA and malonyl CoA for fatty acid synthesis. Fatty acids are incorporated as phospholipids into cell membranes. ACC = acetyl-CoA carboxylase; ATP $=$ adenosine triphosphate; $\mathrm{FADH}_{2}=$ reduced form of flavin adenine dinucleotide; $\mathrm{NADH}=$ nicotinamide adenine dinucleotide hydrate; TCA $=$ tricarboxylic acid.

of ${ }^{11} \mathrm{C}$-acetate in the proximal convoluted tubule. Pancreas, kidneys, spleen, heart, and liver received the highest organ doses. The consistently high tracer uptake in the pancreas was recently exploited for secretin testing of the pancreatic exocrine function (25). The effective whole-body dose was low, at $0.0049 \mathrm{mSv} / \mathrm{MBq}$. The same authors developed a model to describe acetate kinetics in prostate cancer (Fig. 3) (26).

\section{${ }^{11} \mathrm{C}$-ACETATE AS A DIAGNOSTIC BIOMARKER IN PROSTATE CANCER}

\section{Initially Staging Primary Prostate Cancer}

${ }^{11} \mathrm{C}$-acetate PET cannot reliably distinguish between benign prostatic hyperplasia and prostate cancer. This was systematically demonstrated by Kato et al. (27), who studied 30 research subjects without and 6 patients with prostate cancer. Although the primary prostate cancer was visualized in all patients, differences in the ${ }^{11} \mathrm{C}$-acetate SUV between the subjects aged 50 years and older with normal prostate or benign prostatic hyperplasia and the patients with prostate cancer were not statistically significant. In fact, the normal prostate showed increasing ${ }^{11} \mathrm{C}$-acetate uptake with age. Somewhat contradictory findings were provided by Mena et al. (28), who demonstrated that ${ }^{11} \mathrm{C}$-acetate uptake in tumor was higher than that in normal prostate tissue. However, those authors confirmed that benign prostatic hyperplasia and cancer were indistinguishable. This finding was also previously reported quantitatively using a 3-compartment tracer kinetic model (26).

Despite the comparable tracer uptake in benign prostatic hyperplasia and cancer, the diagnostic accuracy of ${ }^{11} \mathrm{C}$-acetate PET for detecting primary prostate cancer was evaluated by several groups (Table 1). One of the earliest studies enrolled 22 patients with recently diagnosed prostate cancer (29). ${ }^{11} \mathrm{C}$-acetate PET detected prostate cancer with a sensitivity of $100 \%$, which was superior to that of ${ }^{18}$ F-FDG. Mean SUVs ranged from 3.3 to 9.9 and were higher than those of ${ }^{18} \mathrm{~F}-\mathrm{FDG}$. The relatively high number of true- positive ${ }^{18} \mathrm{~F}-\mathrm{FDG}$ studies is likely explained by the fairly advanced disease in 14 of the 22 patients, as evidenced by serum prostatespecific antigen (PSA) levels greater than $20 \mathrm{ng} / \mathrm{mL}$ in 15 patients. Because of the study design-only patients with known cancer were included - no data on specificity were provided.

In the study by Mena et al. (28), 38 patients with presumed localized prostate cancer underwent ${ }^{11} \mathrm{C}$-acetate PET/CT and multiparametric MRI. All patients underwent prostatectomy after the scans. Serum PSA levels averaged $7.0 \pm 8.9 \mathrm{ng} / \mathrm{mL}$ and ranged from 1.1 to $54 \mathrm{ng} / \mathrm{mL}$. Fifteen patients had serum PSA levels of less than $4 \mathrm{ng} / \mathrm{mL}$. On histopathology, 167 tumor foci were identified; 80 of those were larger than $5 \mathrm{~mm}$. On a per-patient basis, PET/CT and MRI detected cancer in 34 and 37 of the 38 patients, respectively. On a lesion-based analysis, MRI was more sensitive than PET/CT (88.5\% for combined MRI approaches vs. $73.4 \%$ for PET/CT; $P$ value was not provided). Detectability with PET depended on lesion size rather than serum PSA levels (28).

Jambor et al. (30) evaluated 36 patients with untreated, nonmetastatic prostate cancer. Histopathology from prostatectomy $(n=10)$ and biopsy $(n=26)$ served as the standard of reference. Serum PSA levels averaged $9.8 \pm 6.3 \mathrm{ng} / \mathrm{mL}$ (range, 2.9 $30 \mathrm{ng} / \mathrm{mL}$ ). A high sensitivity of $88 \%$ but a low specificity of $41 \%$ were reported at a lobe-based analysis (30). The same authors reported an even lower specificity when data analysis

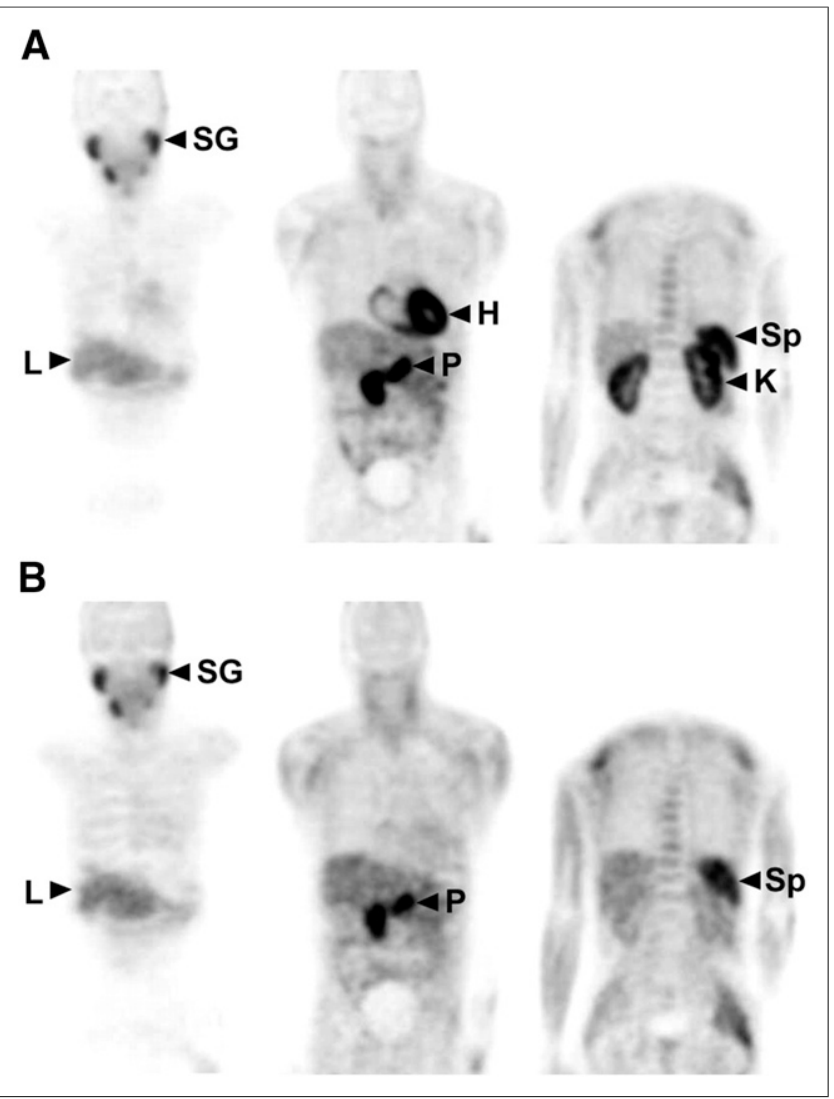

FIGURE 2. Whole-body ${ }^{11} \mathrm{C}$-acetate biodistribution images were obtained at 2 min (A) and 28 min (B). Note complete washout of heart activity and significant clearance from kidneys at later time point. Also note absence of bladder activity throughout study. $\mathrm{H}=$ heart; $\mathrm{K}=$ kidney; $\mathrm{L}=$ liver; $\mathrm{P}=$ pancreas; $\mathrm{SG}=$ salivary glands; $\mathrm{Sp}=$ spleen. Reprinted from (24). 


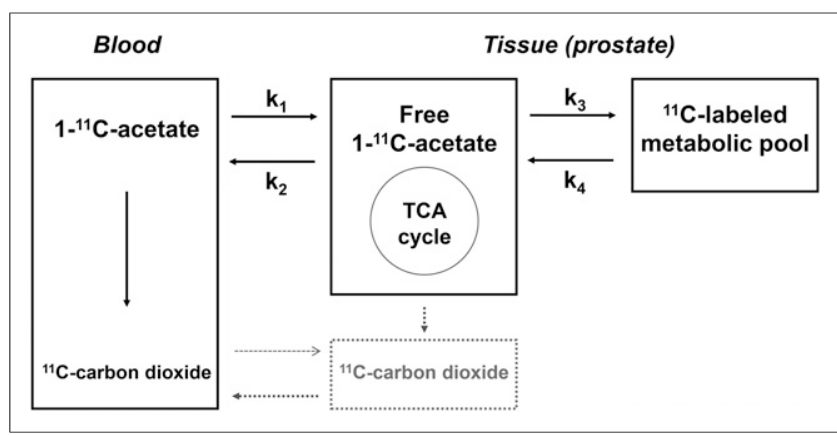

FIGURE 3. Kinetic model with 3 compartments and 2 tissues for prostate gland. $\mathrm{CO}_{2}$ concentration in tissue is low because of low intracellular $\mathrm{pH}$. Intracellularly labeled $\mathrm{CO}_{2}$ (gray box) is negligible. Blood-to-tissue transport is minimal (gray arrow). Most labeled $\mathrm{CO}_{2}$ is transported rapidly to blood as part of $k_{2}$. Metabolic pool consists of precursors for lipids, amino acids, fatty acids, and steroids that trap or retain ${ }^{11} \mathrm{C}$ label. Labeled products of cycle also contribute to metabolic pool (as part of $k_{3}$ ). Increase in tricarboxylic acid cycle metabolism would lead to increase in both $k_{2}$ and $k_{3}$. TCA = tricarboxylic acid. Reprinted from (26).

was limited to patients without extraprostatic cancer extension (31). Tumor aggressiveness (Gleason score) and degree of ${ }^{11} \mathrm{C}$ acetate uptake were unrelated (31). The low specificity may have been accounted for by benign prostatic hyperplasia. However, uptake in inflammatory cells may also have contributed to false-positive findings. Data from Schöder et al. (32) support this notion because a fairly large number of false-positive lymph nodes caused by granulomatous disease (possibly related to prior intravesical bacillus Calmette-Guerin treatment) were observed in their study. Consistently, another group reported increased ${ }^{11} \mathrm{C}$-choline uptake in a murine model of Chlamydia muridarum genital infection (33). Taken together, these data suggest that activation of lipid synthetic pathways very likely also occurs in rapidly proliferating inflammatory cells, accounting for false-positive findings.

\section{Assessing Regional Lymph Node Involvement}

As shown in Table 1 , the ability of ${ }^{11} \mathrm{C}$-acetate PET to evaluate pelvic lymph nodes was determined in 4 studies. The first study included 107 patients with recently diagnosed intermediate- or high-risk prostate cancer who underwent primary surgery (34). All were imaged before surgery and were followed clinically to identify patients whose treatment failed and to determine whether this failure was associated with presurgical ${ }^{11} \mathrm{C}$-acetate PET findings. Presurgical PET identified abnormal ${ }^{11} \mathrm{C}$-acetate uptake in the prostate in 103 of the 107 patients. Metastases were seen in $34 \%$ of the 107 patients, mostly involving pelvic lymph nodes. The 36 patients with positive lymph nodes on PET had higher Gleason scores and pathology stages than did the patients with negative PET results. Although the sensitivity and specificity of ${ }^{11} \mathrm{C}$-acetate PET were modest on a per-patient basis, at $68 \%$ and $78 \%$, respectively, a multivariate analysis showed that presurgical metastases identified on PET were independently and

TABLE 1

Studies in Patients with Primary Prostate Cancer and Lymph Node Involvement

\begin{tabular}{|c|c|c|c|c|c|c|}
\hline Study & Journal & $\begin{array}{c}\text { No. of } \\
\text { patients }\end{array}$ & $\begin{array}{c}\text { Sensitivity } \\
(\%)\end{array}$ & $\begin{array}{l}\text { Specificity } \\
(\%)\end{array}$ & PSA level (ng/mL) & Comments \\
\hline $\begin{array}{l}\text { Kato et al. (27), } \\
2002\end{array}$ & EJNMMI & 6 & 100 & ND & Mean, 1,790.2 (0.3-6,954.8) & Primary prostate cancer \\
\hline $\begin{array}{l}\text { Mena et al. (28), } \\
2012\end{array}$ & $J$ Nucl Med & 39 & 73.4 & ND & Mean, 7 (1.1-54) & $\begin{array}{l}\text { Primary prostate cancer } \\
\text { (lesion-based analysis) }\end{array}$ \\
\hline $\begin{array}{l}\text { Oyama et al. (29), } \\
2002\end{array}$ & $J$ Nucl Med & 22 & 100 & - & Mean, 71.3 (1.9-296) & Primary prostate cancer \\
\hline $\begin{array}{l}\text { Jambor et al. (30), } \\
2012\end{array}$ & Eur J Radiol & 36 & 88 & $41 \%$ & Mean, 9.8 (2.9-30) & Primary prostate cancer \\
\hline $\begin{array}{l}\text { Jambor et al. (31), } \\
2010\end{array}$ & $J$ Nucl Med & 21 & 80 & 29 & Mean, 10.1 (2.9-30) & Primary prostate cancer \\
\hline $\begin{array}{l}\text { Haseebuddin } \\
\text { et al. (34), } 2013\end{array}$ & $J$ Nucl Med & 107 & $68^{*}$ & 78 & Median, 11.8 (1.4-225.4) & Initial lymph node staging \\
\hline $\begin{array}{l}\text { Daouacher } \\
\text { et al. (35), } 2015\end{array}$ & BJU Int & 53 & 38 & 96 & Mean, 24 (3-112) & Initial lymph node staging \\
\hline $\begin{array}{l}\text { Strandberg } \\
\text { et al. (36), } 2014\end{array}$ & EJNMMI Res & 50 & ND & ND & Mean, 37 (2.7-168) & Initial lymph node staging \\
\hline $\begin{array}{l}\text { Schumacher } \\
\text { et al. (38), } 2015\end{array}$ & Scand J Urol & 19 & 90 & 67 & Mean, 19.1 (0.1-130) & Initial lymph node staging \\
\hline Total & & 353 & & & & \\
\hline \multicolumn{7}{|c|}{$\begin{array}{l}{ }^{* 11} \mathrm{C} \text {-acetate uptake (focal or diffuse) in prostate gland was seen in } 103 \text { of } 107 \text { patients (96\%) who had previously been diagnosed wit } \\
\text { rostate cancer. }\end{array}$} \\
\hline
\end{tabular}


significantly associated with a 3.26-fold higher risk for treatment failure. This independent predictive power was maintained after surgery when the study was controlled for other postsurgical factors such as pathology stage, surgical Gleason score, and surgical margins.

The second study reported a lower sensitivity in 53 patients with newly diagnosed prostate cancer (35). Histopathology was the gold standard in all patients. The patient-based sensitivity for detecting lymph node involvement was only $38 \%$, with a specificity of $96 \%$ and an accuracy of $68 \%$. Positivity by ${ }^{11} \mathrm{C}$-acetate was associated with a greater number and larger size of involved nodes. Thus, because of the inability of ${ }^{11} \mathrm{C}$-acetate PET to detect small tumor-involved lymph nodes, the sensitivity of the test for lymph node involvement was not sufficiently high for its routine use to be recommended.

Another study enrolled 50 consecutive patients with highaverage serum PSA levels and Gleason scores who were scheduled to undergo primary radiation treatment (36). This group was evaluated for whether the degree and extent of ${ }^{11} \mathrm{C}$-acetate PET abnormalities were associated with the estimated risk for pelvic lymph node metastases according to the nomogram described by Cagiannos et al. (37). Interestingly, the imaging approach was a better predictor of lymph node involvement than the nomogram. PET findings also affected patient management by changing the radiation approach in more than $40 \%$ of the patients.

The final study was performed in 19 patients before initial surgery (38). Pelvic lymph node dissection was the reference standard. Sensitivity and specificity on a patient basis were $90 \%$ and $67 \%$, respectively. False-positive nodes were most likely due to inflammation. Importantly, nodal station-based analysis revealed a sensitivity of only $62 \%$.

In summary, the available data on primary prostate cancer detection and lymph node staging with ${ }^{11} \mathrm{C}$-acetate are sparse. However, because of the modest sensitivity and specificity of ${ }^{11} \mathrm{C}$-acetate PET, it appears unlikely that this imaging approach will be helpful to diagnose, localize, and stage primary prostate cancers in patients with elevated PSA levels. The study by Haseebuddin et al. (34) suggests that prognostic information can be derived from presurgical ${ }^{11} \mathrm{C}$-acetate studies. In another report, ${ }^{11} \mathrm{C}$-acetate studies performed before radiation therapy altered the management in more than $40 \%$ of patients (36). These potential applications await further verification in larger prospective studies.

\section{Identifying and Localizing the Source of Biochemical Recurrence}

Biochemical evidence of prostate cancer recurrence (Table 2) after radical prostatectomy or radiation treatment, defined as a serum PSA level of $0.2 \mathrm{ng} / \mathrm{mL}$ or greater, frequently precedes the clinical manifestations of recurrent disease in the prostate bed, in regional lymph nodes, or at distant sites such as lymph nodes or bones. Local salvage therapy (radiation or surgery) is used in patients with regional pelvic lymph node and prostate bed recurrence, whereas systemic therapy is required to address distant metastases. In patients with locally recurrent disease, salvage radiation therapy can improve survival (39). Once metastatic disease develops, the prognosis is guarded, with a mean patient survival of $5 \mathrm{y}(40)$. Therefore, early and accurate detection of the site of recurrence is critically important for patient management and therapy decisions. Figure 4 shows a representative case.
It is important to understand the sensitivity or diagnostic range of ${ }^{11} \mathrm{C}$-acetate- and choline-based PET probes in prostate cancer assessments. Although ${ }^{11} \mathrm{C}$-acetate has the advantage of low or no urinary excretion, ${ }^{18} \mathrm{~F}$-choline is more widely available because of its longer physical half-life. ${ }^{11} \mathrm{C}$-acetate and ${ }^{11} \mathrm{C}$-choline identified approximately only $50 \%$ of recurrence sites in patients with PSA levels of less than $1 \mathrm{ng} / \mathrm{mL}$ (41). Endorectal MRI was superior because it identified recurrence in 15 of 18 patients, suggesting that it was the modality of choice in patients with low serum PSA levels and a low likelihood of distant disease. In another small study in a mixed population of patients with primary or recurrent prostate cancer, ${ }^{11} \mathrm{C}$-choline and ${ }^{11} \mathrm{C}$-acetate failed to detect small-volume disease (42). In general, a high concordance between ${ }^{11} \mathrm{C}$-acetate and ${ }^{11} \mathrm{C}$ - or ${ }^{18} \mathrm{~F}$-choline findings is evident. For instance, ${ }^{18} \mathrm{~F}$-choline and ${ }^{11} \mathrm{C}$-acetate performed nearly identically in 23 patients with biochemical recurrence after various primary therapeutic approaches. Disease was detected in only 3 of 6 patients having serum PSA levels of less than $1.0 \mathrm{ng} / \mathrm{dL}$. However, detection rates increased with increasing PSA levels (43).

In an early clinical ${ }^{11} \mathrm{C}$-acetate study using dedicated PET systems in 31 patients, sites of recurrence were identified in 18 patients by biopsy (44). PET correctly identified 15 of these 18 patients. Importantly, disease sites were identified in 5 of 8 patients with serum PSA levels of less than $2.0 \mathrm{ng} / \mathrm{mL}$. No false-positive findings were reported (44).

Oyama et al. (45) reported positive ${ }^{11} \mathrm{C}$-acetate findings in 59\% of 46 patients with biochemical recurrence who were studied using a dedicated PET system. This study group included patients who had undergone prostatectomy $(n=30)$ and primary radiation treatment $(n=16)$. Their mean serum PSA levels were 4.9 and $5.8 \mathrm{ng} / \mathrm{mL}$, respectively. Sites of recurrence remained in essence undetected in patients with serum PSA levels of less than $3 \mathrm{ng} / \mathrm{mL}$. It appears quite likely that this comparably low yield is due to the lack of integrated PET/CT technology, which became available only later (46).

Good detection rates of early recurrences were reported by Albrecht et al. (47), who studied 32 patients. One group of patients had been treated with radiation, and another had undergone prostatectomy. Both had evidence of biochemical recurrence. However, median serum PSA levels were lower in the surgical group (mean, $0.4 \mathrm{ng} / \mathrm{mL}$ ) than in the postradiation group (mean, $6 \mathrm{ng} / \mathrm{mL}$ ). Identification of recurrence sites was significantly better in the latter group. However, detection of bone involvement was suboptimal.

True-positive findings in 15 of 20 patients but false-positive findings in 3 of 20 were reported by Sandblom et al. (48). This population, which was imaged with $\mathrm{PET} / \mathrm{CT}$, included patients with low-average serum PSA levels of $2.0 \mathrm{ng} / \mathrm{mL}$; one site of recurrence was detected in a patient with a serum PSA level of $0.5 \mathrm{ng} / \mathrm{mL}$. All patients with serum PSA levels of $2.0 \mathrm{ng} / \mathrm{mL}$ or greater showed abnormal probe uptake. Lung cancer, esophagitis, and nonspecific lymphadenopathy accounted for the 3 false-positive findings. The existence of false-positives is not surprising because of the high proliferation rates of cancer and inflammatory cells, resulting in increased requirements for membrane lipids.

A large retrospective analysis including 120 patients was published recently (49). Sixty-eight percent of the scans had positive findings for disease recurrence. Rates of positivity increased with serum PSA levels and PSA velocity. Using a PSA velocity 
TABLE 2

Studies in Prostate Cancer Patients with Biochemical Recurrence

\begin{tabular}{|c|c|c|c|c|c|c|}
\hline Study & Journal & $\begin{array}{l}\text { No. of } \\
\text { patients }\end{array}$ & $\begin{array}{c}\text { Sensitivity } \\
(\%)\end{array}$ & $\begin{array}{l}\text { Specificity } \\
(\%)\end{array}$ & PSA level (ng/mL) & Comments \\
\hline $\begin{array}{l}\text { Vees } \\
\text { et al. (41), } \\
2007\end{array}$ & BJU Int & 11 & 66 & ND & Mean, 0.06 (0.00-0.51) & \\
\hline $\begin{array}{l}\text { Buchegger } \\
\text { et al. (43), } \\
2014\end{array}$ & EJNMMI & 23 & ND & ND & $\begin{array}{l}\text { Mean, } 1.1 \text { after prostatectomy, } \\
3.5 \text { after radiotherapy, } 2.4 \\
\text { after prostatectomy }+ \text { salvage } \\
\text { radiotherapy }\end{array}$ & $\begin{array}{l}\text { High concordance between } \\
{ }^{18} \mathrm{~F} \text {-choline and }{ }^{11} \mathrm{C} \text {-acetate } \\
\text { findings }\end{array}$ \\
\hline $\begin{array}{l}\text { Kotzerke } \\
\text { et al. (44), } \\
2002\end{array}$ & EJNMMI & 31 & ND & ND & Mean, 15.2 (0.1-150.6) & $\begin{array}{l}15 \text { of } 18 \text { patients }(83 \%) \text { with } \\
\text { biopsy-proven recurrence } \\
\text { were true-positive; } 5 \text { of } \\
8(63 \%) \text { were }{ }^{11} \mathrm{C} \text {-acetate- } \\
\text { positive with PSA }<2.0 \mathrm{ng} / \mathrm{mL} \\
\text { (4 of these } 5 \text { had histologically } \\
\text { proven disease) }\end{array}$ \\
\hline $\begin{array}{l}\text { Oyama } \\
\text { et al. (45), } \\
2003\end{array}$ & J Nucl Med & 46 & 59 & ND & $\begin{array}{l}\text { Mean, } 4.9(0.3-47.5) \text { after } \\
\text { prostatectomy, } \\
5.8(0.5-11.5) \text { after } \\
\text { radiotherapy, PSA } \\
\text { threshold of } 3 \mathrm{ng} / \mathrm{mL}\end{array}$ & $\begin{array}{l}13 \text { of } 22 \text { patients }(59 \%) \text { with } \\
\text { PSA }>3 \text { ng/mL were } \\
{ }^{11} \mathrm{C} \text {-acetate-positive; } 1 \text { of } \\
24(4 \%) \text { with PSA } \leq 3 \mathrm{ng} / \mathrm{mL} \\
\text { was }{ }^{11} \mathrm{C} \text {-acetate-positive }\end{array}$ \\
\hline $\begin{array}{l}\text { Albrecht } \\
\text { et al. (47), } \\
2007\end{array}$ & EJNMMI & 32 & ND & ND & $\begin{array}{l}\text { Mean, } 10.4(2.6-30.2) \\
\text { after radiotherapy, } \\
1.2(0.08-4.8) \text { after } \\
\text { radical surgery }\end{array}$ & $\begin{array}{l}14 \text { of } 17 \text { patients ( } 82 \%) \\
\text { after radiotherapy were } \\
{ }^{11} \mathrm{C} \text {-acetate-positive; } 5 \text { of } \\
15(33 \%) \text { after radical surgery } \\
\text { were }{ }^{11} \mathrm{C} \text {-acetate-positive }\end{array}$ \\
\hline $\begin{array}{l}\text { Sandblom } \\
\text { et al. (48), } \\
2006\end{array}$ & Urology & 20 & 75 & ND & Median, 2.0 (0.5-8.1) & \\
\hline $\begin{array}{l}\text { Dusing } \\
\text { et al. (49), } \\
2014\end{array}$ & Clin Nucl Med & 120 & $74^{\star}, 87^{\dagger}$ & $75^{\star}, 66^{\dagger}$ & $\begin{array}{l}\text { Mean, } 7.6 \text { (in } 119 \\
\text { patients, 0.20-127.32) }\end{array}$ & \\
\hline $\begin{array}{l}\text { Wachter } \\
\text { et al. (52), } \\
2006\end{array}$ & J Clin Oncol & 50 & 92 & 60 & Range, 0.5-24.9 & $\begin{array}{l}\text { In } 12 \text { patients with } \\
\text { histopathologic verification }\end{array}$ \\
\hline $\begin{array}{l}\text { Spick } \\
\text { et al. (54), } \\
2015\end{array}$ & Anticancer Res & 90 & 90 & 96.1 & Mean, 41.8 (0.3-551.1) & In bone metastasis \\
\hline Total & & 423 & & & & \\
\hline \multicolumn{7}{|c|}{$\begin{array}{l}{ }^{*} \mathrm{PSA} \text { levels of }>1.24 \mathrm{ng} / \mathrm{mL} \text { as threshold. } \\
{ }^{\dagger} \mathrm{PSA} \text { velocity threshold of }>1.32 \mathrm{ng} / \mathrm{mL} / \mathrm{y} \text { as threshold. } \\
\mathrm{ND}=\text { not determined. } \\
\text { Data in parentheses are ranges. }\end{array}$} \\
\hline
\end{tabular}

threshold of $1.32 \mathrm{ng} / \mathrm{mL} / \mathrm{y}$ resulted in sensitivity and specificity of $74 \%$ and $75 \%$, respectively. A serum PSA level of $1.24 \mathrm{ng} / \mathrm{mL}$ was associated with a sensitivity and specificity of $87 \%$ and $66 \%$, respectively. These data are equivalent to reports on ${ }^{11} \mathrm{C}$-choline $(50,51)$.

A study that used PET/MRI software fusion may have provided insights into the potential of integrated PET/MRI for prostate cancer imaging (52). A software approach to fuse ${ }^{11} \mathrm{C}$ acetate PET, CT, and MR images was used in 50 patients who had been treated with radical prostatectomy (mean serum PSA level, $6.3 \mathrm{ng} / \mathrm{mL}$ ), external beam radiation (mean serum PSA level, $12.4 \mathrm{ng} / \mathrm{mL}$ ), or seed implantation (mean serum PSA level, $9.9 \mathrm{ng} / \mathrm{mL}$ ). All had biochemical recurrence. The authors reported that image fusion improved diagnostic information. For instance, fusion with MRI revealed 9 malignant and 5 benign etiologies in 14 patients with equivocal PET findings. Fusion with MR images was more informative than fusion with CT images, suggesting an important potential indication for integrated clinical PET/MRI in patients with recurrent prostate cancer. As a limitation, only a relatively small number of lesions was verified histopathologically. However, clinical management was changed in $28 \%$ of the patients. 


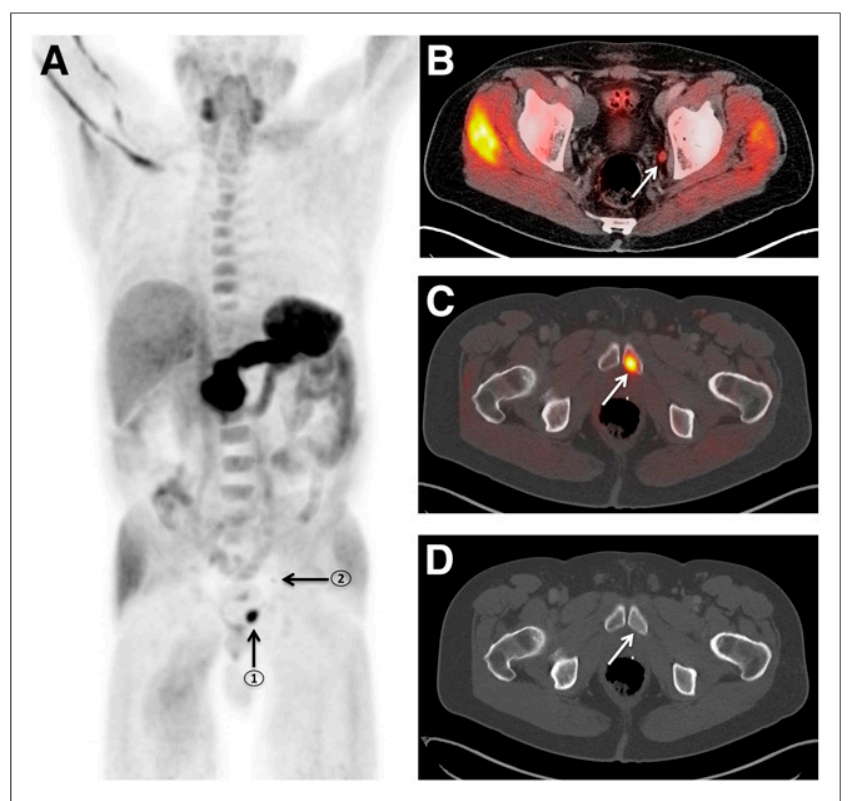

FIGURE 4. Images of 59-y-old prostate cancer patient with biochemical recurrence (serum PSA level, $2.2 \mathrm{ng} / \mathrm{mL}$ ). (A) Coronal whole-body PET image reveals focally increased uptake near pubic symphysis (1) and mild uptake in left internal iliac lymph node (2). (B-D) Axial ${ }^{11} \mathrm{C}-$ acetate PET/CT images depict hypermetabolic left internal iliac lymph node (arrow, B) and pubic symphysis lesion (arrow, C), as well as mild sclerosis that was identified only in retrospect in bone windows (arrow, D).

\section{Assessing Distant Metastatic Disease}

A small study of 8 patients demonstrated that distant disease was detected in one more patient with ${ }^{11} \mathrm{C}$-acetate than with ${ }^{18} \mathrm{~F}$ FDG (53). Whether this difference is clinically meaningful is unknown. In a more recent and much larger study, Spick et al. (54) retrospectively compared conventional bone scans with ${ }^{11} \mathrm{C}$ acetate PET findings for detecting bone metastases in 90 patients with rising PSA levels after initial definitive therapy. Clinical and imaging follow-up served as the reference standard. Conventional bone scans and ${ }^{11} \mathrm{C}$-acetate PET were comparable on a patient-based analysis. This observation suggests that ${ }^{11} \mathrm{C}$ acetate PET imaging can reliably survey the whole body for bone involvement.

\section{${ }^{11} \mathrm{C}$-ACETATE AS A PREDICTIVE, PROGNOSTIC, AND INTERMEDIATE ENDPOINT BIOMARKER}

Well-designed prospective clinical studies to determine whether ${ }^{11} \mathrm{C}$-acetate can serve as a predictive, prognostic, or intermediate endpoint biomarker are lacking. Predictive biomarkers are designed to determine whether a specific therapeutic target is expressed (Fig. 5) (55). FAS is overexpressed in prostate and other cancers and has been explored as a potential therapeutic target. Orlistat, a selective inhibitor of FAS, was tested for target inhibition in murine prostate cancer models. The degree of target expression as determined with ${ }^{11} \mathrm{C}$-acetate imaging correlated with response to FAS inhibition (55).

Limited information on the prognostic value of ${ }^{11} \mathrm{C}$-acetate PET imaging is available. In one study of 123 patients with biochemical recurrence, ${ }^{11} \mathrm{C}$-acetate uptake was associated with higher PSA velocity (ng/mL/mo). Further significant correlations

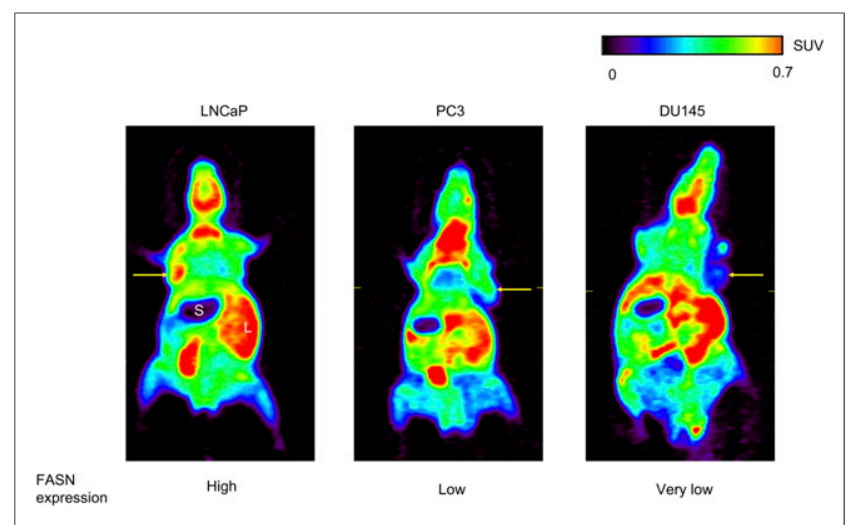

FIGURE 5. Three different tumor xenografts (arrows) having various expression levels of $F A S N$ gene exhibit proportional ${ }^{11} \mathrm{C}$-acetate uptake. $\mathrm{L}=$ liver; $\mathrm{S}=$ stomach. Adapted and reprinted from (55).

with the initial Gleason score also suggest the prognostic value of ${ }^{11} \mathrm{C}$-acetate imaging in biochemically recurrent prostate cancer (56).

We are unaware of clinical studies that have systematically evaluated ${ }^{11} \mathrm{C}$-acetate as an intermediate endpoint biomarker. In a preclinical study, mice were imaged with ${ }^{18} \mathrm{~F}-\mathrm{FDG}$ and ${ }^{11} \mathrm{C}$ acetate before and after androgen ablation (57). Diethylstilbestrol treatment caused a decrease in ${ }^{18} \mathrm{~F}$-FDG uptake in prostate tumors, whereas a change in acetate tumor uptake in the androgen ablation mice was not significant. Rather than indicating a failure of ${ }^{11} \mathrm{C}$-acetate to demonstrate treatment-induced changes, these findings point to our need to better understand the interplay among various metabolic pathways and their alterations in response to therapy.

Anecdotal evidence suggests that ${ }^{11} \mathrm{C}$-acetate may be useful as an intermediate endpoint biomarker in prostate cancer treatment. Changes in ${ }^{11} \mathrm{C}$-acetate $6-12 \mathrm{wk}$ after the start of systemic therapy correlated with clinical response in 6 patients (53).

\section{VALUE OF ${ }^{11} \mathrm{C}$-ACETATE IN THE PORTFOLIO OF PET IMAGING PROBES IN PROSTATE CANCER}

For 2 decades, PET imaging of prostate cancer was considered frustrating because of the perceived paucity of useful imaging markers. With regard to diagnostic accuracy for initial detection and staging, this negative bias is understandable. However, with regard to disease phenotyping, the imaging community offers a wide spectrum of metabolic, peptide receptor, and antibody PET probes, which are addressed elsewhere in this supplement. Glucose metabolic PET imaging in prostate cancer is underappreciated. For instance, ${ }^{18} \mathrm{~F}-\mathrm{FDG}$ and ${ }^{11} \mathrm{C}$-acetate were compared in a mixed population of patients with primary and recurrent prostate cancer. This study provided interesting insights into different metabolic phenotypes. Bone metastases were more glycolytic than primary prostate cancer lesions and pelvic lymph node metastases that showed higher ${ }^{11} \mathrm{C}$-acetate avidity, suggesting different metabolic needs of primary versus metastatic lesions (58). The phenotypic information derived for primary and metastatic lesions may well provide critically important prognostic and predictive information and may help us arrive at more precise treatment approaches. 


\section{CONCLUSION}

A wealth of novel imaging probes, together with emerging technologies such as PET/MRI, raises expectations that molecular PET imaging will have a significant role in the management of patients with prostate cancer. How each of the available PET probes will best be deployed remains to be determined.

\section{DISCLOSURE}

Johannes Czernin is a founder and shareholder of Sofie Biosciences and Trethera Therapeutics. Ken Herrmann is a consultant of Sofie Biosciences. No other potential conflict of interest relevant to this article was reported.

\section{REFERENCES}

1. Armbrecht JJ, Buxton DB, Schelbert HR. Validation of $1-{ }^{11} \mathrm{C}$-acetate as a tracer for noninvasive assessment of oxidative metabolism with positron emission tomography in normal, ischemic, postischemic, and hyperemic canine myocardium. Circulation. 1990;81:1594-1605.

2. Buxton DB, Nienaber CA, Luxen A, et al. Noninvasive quantitation of regional myocardial oxygen consumption in vivo with $1-{ }^{11} \mathrm{C}$-acetate and dynamic positron emission tomography. Circulation. 1989;79:134-142.

3. Buxton DB, Schwaiger M, Nguyen A, Phelps ME, Schelbert HR. Radiolabeled acetate as a tracer of myocardial tricarboxylic acid cycle flux. Circ Res. 1988;63: 628-634.

4. Gropler RJ, Siegel BA, Geltman EM. Myocardial uptake of ${ }^{11} \mathrm{C}$-acetate as an indirect estimate of regional myocardial blood flow. J Nucl Med. 1991;32:245251.

5. Knowles LM, Yang C, Osterman A, Smith JW. Inhibition of fatty-acid synthase induces caspase-8-mediated tumor cell apoptosis by up-regulating DDIT4. J Biol Chem. 2008;283:31378-31384.

6. Waniewski RA, Martin DL. Preferential utilization of acetate by astrocytes is attributable to transport. J Neurosci. 1998;18:5225-5233.

7. Yoshii Y, Furukawa T, Saga T, Fujibayashi Y. Acetate/acetyl-CoA metabolism associated with cancer fatty acid synthesis: overview and application. Cancer Lett. 2015;356:211-216.

8. Kennedy EP, Weiss SB. The function of cytidine coenzymes in the biosynthesis of phospholipides. J Biol Chem. 1956;222:193-214.

9. Brown M, Marshall DR, Sobel BE, Bergmann SR. Delineation of myocardial oxygen utilization with carbon-11-labeled acetate. Circulation. 1987;76:687696.

10. Brown MA, Myears DW, Bergmann SR. Validity of estimates of myocardial oxidative metabolism with ${ }^{11} \mathrm{C}$-acetate and positron emission tomography despite altered patterns of substrate utilization. J Nucl Med. 1989;30:187-193.

11. Gropler RJ, Siegel BA, Sampathkumaran K, et al. Dependence of recovery of contractile function on maintenance of oxidative metabolism after myocardial infarction. J Am Coll Cardiol. 1992;19:989-997.

12. Henes CG, Bergmann SR, Walsh MN, Sobel BE, Geltman EM. Assessment of myocardial oxidative metabolic reserve with positron emission tomography and ${ }^{11}$ C-acetate. J Nucl Med. 1989;30:1489-1499.

13. Walsh MN, Geltman EM, Brown MA, et al. Noninvasive estimation of regional myocardial oxygen consumption by positron emission tomography with ${ }^{11} \mathrm{C}$-acetate in patients with myocardial infarction. J Nucl Med. 1989;30:17981808.

14. Kuhajda FP. Fatty acid synthase and cancer: new application of an old pathway. Cancer Res. 2006;66:5977-5980.

15. Baron V, De Gregorio G, Krones-Herzig A, et al. Inhibition of Egr-1 expression reverses transformation of prostate cancer cells in vitro and in vivo. Oncogene. 2003;22:4194-4204.

16. Epstein JI, Carmichael M, Partin AW. OA-519 (fatty acid synthase) as an independent predictor of pathologic state in adenocarcinoma of the prostate. Urology. 1995;45:81-86.

17. Prowatke I, Devens F, Benner A, et al. Expression analysis of imbalanced genes in prostate carcinoma using tissue microarrays. Br J Cancer. 2007;96:82-88.

18. Vāvere AL, Kridel SJ, Wheeler FB, Lewis JS. $1{ }^{11} \mathrm{C}$-acetate as a PET radiopharmaceutical for imaging fatty acid synthase expression in prostate cancer. $\mathrm{J} \mathrm{Nucl}$ Med. 2008;49:327-334.
19. Buchanan JM, Hastings AB, Nesbett FB. The rôle of carboxyl-labeled acetic, propionic, and butyric acids in liver glycogen formation. $J$ Biol Chem. $1943 ; 150: 413-425$.

20. Winstead MB, Lamb JF, Winchell HS. Relationship of chemical structure to in vivo scintigraphic distribution patterns of ${ }^{11} \mathrm{C}$ compounds. $1 .{ }^{11} \mathrm{C}$-carboxylates. J Nucl Med. 1973;14:747-754.

21. Pike VW, Eakins MN, Allan RM, Selwyn AP. Preparation of $1-^{11}$ C-acetate: an agent for the study of myocardial metabolism by positron emission tomography. Int J Appl Radiat Isot. 1982;33:505-512.

22. Hoffmann EJ, Phelps ME, Mullani NA, Higgins CS, Terpogossian MM. Design and performance characteristics of a whole-body positron transaxial tomograph. J Nucl Med. 1976;17:493-502.

23. Shreve P, Chiao PC, Humes HD, Schwaiger M, Gross MD. ${ }^{11}$ C-acetate PET imaging in renal disease. J Nucl Med. 1995;36:1595-1601.

24. Seltzer MA, Jahan SA, Sparks R, et al. Radiation dose estimates in humans for ${ }^{11} \mathrm{C}$-acetate whole-body PET. J Nucl Med. 2004;45:1233-1236.

25. Hyun OJ, Lodge MA, Jagannath S, Buscaglia JM, Olagbemiro Y, Wahl RL. An exocrine pancreatic stress test with ${ }^{11} \mathrm{C}$-acetate PET and secretin stimulation. J Nucl Med. 2014;55:1128-1131.

26. Schiepers C, Hoh CK, Nuyts J, et al. ${ }^{1-11} \mathrm{C}$-acetate kinetics of prostate cancer. J Nucl Med. 2008;49:206-215.

27. Kato T, Tsukamoto E, Kuge Y, et al. Accumulation of ${ }^{11} \mathrm{C}$-acetate in normal prostate and benign prostatic hyperplasia: comparison with prostate cancer. Eur J Nucl Med Mol Imaging. 2002;29:1492-1495.

28. Mena E, Turkbey B, Mani H, et al. ${ }^{11} \mathrm{C}$-acetate PET/CT in localized prostate cancer: a study with MRI and histopathologic correlation. J Nucl Med. 2012;53:538-545.

29. Oyama N, Akino H, Kanamaru H, et al. ${ }^{11} \mathrm{C}$-acetate PET imaging of prostate cancer. J Nucl Med. 2002;43:181-186.

30. Jambor I, Borra R, Kemppainen J, et al. Improved detection of localized prostate cancer using co-registered MRI and ${ }^{11} \mathrm{C}$-acetate PET/CT. Eur J Radiol. 2012;81:2966-2972.

31. Jambor I, Borra R, Kemppainen J, et al. Functional imaging of localized prostate cancer aggressiveness using ${ }^{11} \mathrm{C}$-acetate $\mathrm{PET} / \mathrm{CT}$ and ${ }^{1} \mathrm{H}-\mathrm{MR}$ spectroscopy. J Nucl Med. 2010;51:1676-1683.

32. Schöder H, Ong SC, Reuter VE, et al. Initial results with ${ }^{11} \mathrm{C}$-acetate positron emission tomography/computed tomography (PET/CT) in the staging of urinary bladder cancer. Mol Imaging Biol. 2012;14:245-251.

33. Marangoni A, Nanni C, Quarta $\mathrm{C}$, et al. Usefulness of ${ }^{11} \mathrm{C}$-choline positron emission tomography for genital chlamydial infection assessment in a BALB/c murine model. Mol Imaging Biol. 2013;15:450-455.

34. Haseebuddin M, Dehdashti F, Siegel BA, et al. ${ }^{11} \mathrm{C}$-acetate PET/CT before radical prostatectomy: nodal staging and treatment failure prediction. $\mathrm{J} \mathrm{Nucl}$ Med. 2013;54:699-706.

35. Daouacher G, von Below C, Gestblom C, et al. Laparoscopic extended pelvic lymph node $(\mathrm{LN})$ dissection as validation of the performance of ${ }^{11} \mathrm{C}$-acetate positron emission tomography/computer tomography in the detection of $\mathrm{LN}$ metastasis in intermediate- and high-risk prostate cancer. BJU Int. June 13, 2015 [Epub ahead of print].

36. Strandberg S, Karlsson CT, Sundström T, Ogren M, Axelsson J, Riklund K. ${ }^{11} \mathrm{C}$ acetate $\mathrm{PET} / \mathrm{CT}$ in pre-therapeutic lymph node staging in high-risk prostate cancer patients and its influence on disease management: a retrospective study. EJNMMI Res. December 5, 2014 [Epub ahead of print].

37. Cagiannos I, Karakiewicz P, Eastham JA, et al. A preoperative nomogram identifying decreased risk of positive pelvic lymph nodes in patients with prostate cancer. J Urol. 2003;170:1798-1803.

38. Schumacher MC, Radecka E, Hellstrom M, Jacobsson H, Sundin A. ${ }^{11}$ C-acetate positron emission tomography-computed tomography imaging of prostate cancer lymph-node metastases correlated with histopathological findings after extended lymphadenectomy. Scand J Urol. 2015;49:35-42.

39. Stephenson AJ, Shariat SF, Zelefsky MJ, et al. Salvage radiotherapy for recurrent prostate cancer after radical prostatectomy. JAMA. 2004;291: 1325-1332.

40. Pound CR, Partin AW, Eisenberger MA, Chan DW, Pearson JD, Walsh PC. Natural history of progression after PSA elevation following radical prostatectomy. JAMA. 1999;281:1591-1597.

41. Vees H, Buchegger F, Albrecht S, et al. ${ }^{18} \mathrm{~F}$-choline and/or ${ }^{11} \mathrm{C}$-acetate positron emission tomography: detection of residual or progressive subclinical disease at very low prostate-specific antigen values $(<1 \mathrm{ng} / \mathrm{mL})$ after radical prostatectomy. BJU Int. 2007;99:1415-1420.

42. Kotzerke J, Volkmer BG, Glatting G, et al. Intraindividual comparison of ${ }^{11} \mathrm{C}$ acetate and ${ }^{11} \mathrm{C}$-choline PET for detection of metastases of prostate cancer. Nuklearmedizin. 2003;42:25-30. 
43. Buchegger F, Garibotto V, Zilli T, et al. First imaging results of an intraindividual comparison of ${ }^{11} \mathrm{C}$-acetate and ${ }^{18} \mathrm{~F}$-fluorocholine $\mathrm{PET} / \mathrm{CT}$ in patients with prostate cancer at early biochemical first or second relapse after prostatectomy or radiotherapy. Eur J Nucl Med Mol Imaging. 2014;41:68-78.

44. Kotzerke J, Volkmer BG, Neumaier B, Gschwend JE, Hautmann RE, Reske SN. ${ }^{11} \mathrm{C}$-acetate positron emission tomography can detect local recurrence of prostate cancer. Eur J Nucl Med Mol Imaging. 2002;29:1380-1384.

45. Oyama N, Miller TR, Dehdashti F, et al. ${ }^{11} \mathrm{C}$-acetate PET imaging of prostate cancer: detection of recurrent disease at PSA relapse. J Nucl Med. 2003;44:549555.

46. Beyer T, Townsend DW, Brun T, et al. A combined PET/CT scanner for clinical oncology. J Nucl Med. 2000;41:1369-1379.

47. Albrecht S, Buchegger F, Soloviev D, et al. ${ }^{11} \mathrm{C}$-acetate PET in the early evaluation of prostate cancer recurrence. Eur J Nucl Med Mol Imaging. 2007;34:185-196.

48. Sandblom G, Sörensen J, Lundin N, Häggman M, Malmström PU. Positron emission tomography with ${ }^{11} \mathrm{C}$-acetate for tumor detection and localization in patients with prostate-specific antigen relapse after radical prostatectomy. Urology. 2006;67:996-1000.

49. Dusing RW, Peng W, Lai SM, et al. Prostate-specific antigen and prostatespecific antigen velocity as threshold indicators in ${ }^{11} \mathrm{C}$-acetate PET/CTAC scanning for prostate cancer recurrence. Clin Nucl Med. 2014;39:777-783.

50. Giovacchini G, Picchio M, Coradeschi E, et al. Predictive factors of ${ }^{11} \mathrm{C}$-choline PET/CT in patients with biochemical failure after radical prostatectomy. Eur $J$ Nucl Med Mol Imaging. 2010;37:301-309.
51. Giovacchini G, Picchio M, Scattoni V, et al. PSA doubling time for prediction of ${ }^{11} \mathrm{C}$-choline PET/CT findings in prostate cancer patients with biochemical failure after radical prostatectomy. Eur J Nucl Med Mol Imaging. 2010;37:1106-1116.

52. Wachter S, Tomek S, Kurtaran A, et al. ${ }^{11} \mathrm{C}$-acetate positron emission tomography imaging and image fusion with computed tomography and magnetic resonance imaging in patients with recurrent prostate cancer. J Clin Oncol. 2006;24: 2513-2519.

53. Yu EY, Muzi M, Hackenbracht JA, et al. ${ }^{11} \mathrm{C}$-acetate and ${ }^{18} \mathrm{~F}-\mathrm{FDG}$ PET for men with prostate cancer bone metastases: relative findings and response to therapy. Clin Nucl Med. 2011;36:192-198.

54. Spick C, Polanec SH, Mitterhauser M, et al. Detection of bone metastases using ${ }^{11} \mathrm{C}$-acetate PET in patients with prostate cancer with biochemical recurrence. Anticancer Res. 2015;35:6787-6791.

55. Yoshii Y, Furukawa T, Oyama N, et al. Fatty acid synthase is a key target in multiple essential tumor functions of prostate cancer: uptake of radiolabeled acetate as a predictor of the targeted therapy outcome. PLoS One. 2013;31;8: e64570.

56. Leisser A, Pruscha K, Ubl P, et al. Evaluation of fatty acid synthase in prostate cancer recurrence: SUV of ${ }^{11} \mathrm{C}$-acetate PET as a prognostic marker. Prostate. 2015;75:1760-1767.

57. Oyama N, Kim J, Jones LA, et al. MicroPET assessment of androgenic control of glucose and acetate uptake in the rat prostate and a prostate cancer tumor model. Nucl Med Biol. 2002;29:783-790.

58. Fricke E, Machtens S, Hofmann M, et al. Positron emission tomography with ${ }^{11} \mathrm{C}$-acetate and ${ }^{18} \mathrm{~F}$-FDG in prostate cancer patients. Eur J Nucl Med Mol Imaging. 2003;30:607-611. 